\title{
Derivatives and Risk Management
}

1.1 Introduction

1.2 Financial Innovation

Expanding Derivatives Markets

Two Economic Motives

1.3 Traded Derivative Securities EXTENSION 1.1 The Influence of Regulations, Taxes, and Transaction Costs on Financial Innovation

Diverse Views on Derivatives Applications and Uses of Derivatives

A Quest for Better Models

1.4 Defining, Measuring, and Managing Risk
1.5 The Regulator's Classification of Risk

1.6 Portfolio Risk Management

1.7 Corporate Financial Risk Management

Risks That Businesses Face

Nonhedged Risks

Risk Management in a Blue Chip Company

1.8 Risk Management

Perspectives in This Book

1.9 Summary

1.10 Cases

1.11 Questions and Problems 


\subsection{Introduction}

The bursting of the housing price bubble, the credit crisis of 2007, the resulting losses of hundreds of billions of dollars on credit derivatives, and the failure of prominent financial institutions have forever changed the way the world views derivatives. Today derivatives are of interest not only to Wall Street but also to Main Street. Derivatives are cursed as one of the causes of the Great Recession of 2007-2009, a period of decreased economic output and high unemployment.

But what are derivatives? A derivative security or a derivative is a financial contract that derives its value from an underlying asset's price, such as a stock or a commodity, or even from an underlying financial index like an interest rate. A derivative can both reduce risk, by providing insurance (which, in financial parlance, is referred to as hedging), and magnify risk, by speculating on future events. Derivatives provide unique and different ways of investing and managing wealth that ordinary securities do not.

Derivatives have a long and checkered past. In the 1960s, only a handful of individuals studied derivatives. No academic books covered the topic, and no college or university courses were available. Derivatives markets were small, located mostly in the US and Western Europe. Derivative users included only a limited number of traders in futures markets and on Wall Street. The options market existed as trading between professional traders (called the over-the-counter [OTC] market) with little activity. In addition, cheating charges often gave the options market disrepute. Derivatives discussion did not add sparkle to cocktail conversations, nor did it generate the allegations and condemnations that it does today. Brash young derivatives traders who drive exotic cars and move millions of dollars with the touch of a computer key didn't exist. Although Einstein had developed the theory of relativity and astronauts had landed on the moon, no one knew how to price an option. That's because in the 1960s, nobody cared, and derivatives were unimportant.

What a difference the following decades have made! Beginning in the early 1970s, derivatives have undergone explosive growth in the types of contracts traded and in their importance to the financial and real economy. According to the Bank for International Settlements (known as the BIS), the markets are now global and measured in trillions of dollars. Indeed, as depicted in Figure 1.1, in December 2016 the total outstanding US dollar notional value for exchange-traded derivatives was $(26,172+41,072=) 67,245$ billion and for OTC derivatives a staggering 500,419 billion. Hundreds of academics study derivatives, and thousands of articles have been written on the topic of pricing derivatives. Colleges and universities now offer numerous derivatives courses using textbooks written on the subject. Derivatives experts are in great demand. In fact, Wall Street firms hire PhDs in mathematics, engineering, and the natural sciences to understand derivatives - these folks are admirably called "rocket scientists" ("quants" is another name). If you understand derivatives, then you know cool stuff; you are hot and possibly dangerous. Today understanding derivatives is an integral part of the knowledge needed in the risk management of financial institutions. 


\section{FIGURE 1.1: Global Derivatives Market}

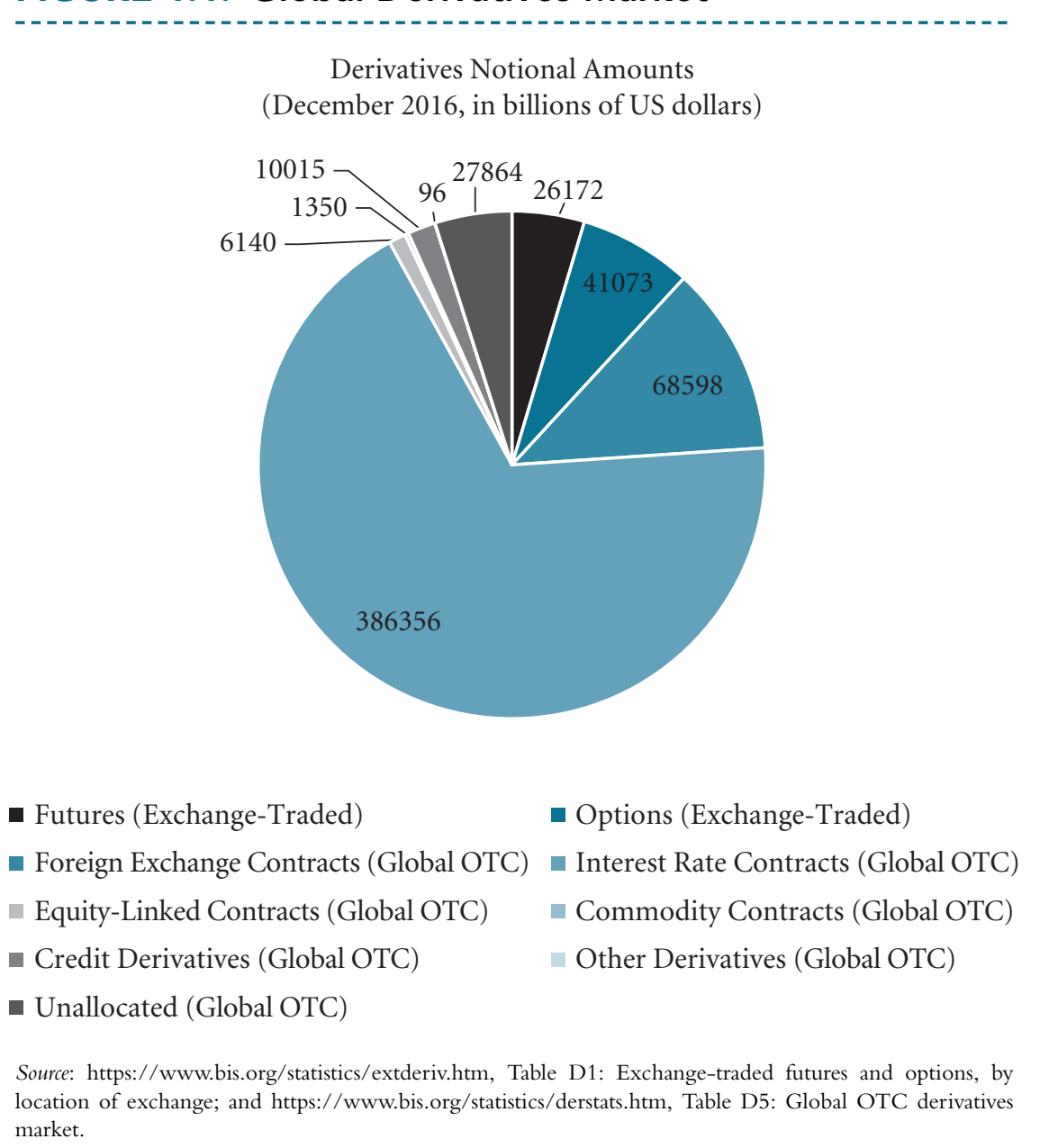

Markets have changed to accommodate derivatives trading in three related ways: the introduction of new contracts and new exchanges, the consolidation and linking of exchanges, and the introduction of computer technology. Sometimes these changes happened with astounding quickness. For example, when twelve European nations replaced their currencies with the euro in 2002, financial markets for eurodenominated interest rate derivatives sprang up almost overnight, and in some cases, they quickly overtook the dollar-denominated market for similar interest rate derivatives.

This chapter tells the fascinating story of this expansion in derivatives trading and the controversy surrounding its growth. An understanding of the meaning of financial risk is essential in fully understanding this story. Hence a discussion of financial risk comes next, from the regulator's, the portfolio manager's, and the corporate financial manager's points of view. We explain each of these unique perspectives, 
using them throughout the book to increase our understanding of the uses and abuses of derivatives. A summary completes the chapter.

\subsection{Financial Innovation}

Derivatives are at the core of financial innovation, for better or for worse. They are the innovations to which columnist David Wessel's Wall Street Journal article titled "A Source of Our Bubble Trouble," dated January 17, 2008, alludes:

Modern finance is, truly, as powerful and innovative as modern science. More people own homes - many of them still making their mortgage payments—because mortgages were turned into securities sold around the globe. More workers enjoy stable jobs because finance shields their employers from the ups and downs of commodity prices. More genius inventors see dreams realized because of venture capital. More consumers get better, cheaper insurance or fatter retirement checks because of Wall Street wizardry.

Expressed at a time when most of the world was in the Great Recession, this view is challenged by those who blame derivatives for the crisis. Indeed, this article goes on to say that "tens of billions of dollars of losses in new-fangled investments [in derivatives and other complex securities] at the largest US financial institutions-and the belated realization that some of those Ph.D. wielding, computer-enhanced geniuses were overconfident in the extreme-strongly suggests some of the brainpower drawn to Wall Street would have been more productively employed elsewhere in the economy."

But derivatives have been trading in various guises for over two thousand years. They have continued to trade because, when used properly, they enable market participants to reduce risk from their portfolios and to earn financial rewards from trading on special skills and information. Indeed, derivatives help to advance or postpone cash flows (borrowing and lending), to accumulate wealth (saving), to protect against unfavorable outcomes (insurance or hedging), to commit funds to earn a financial return (investment), and to accept high risks in the hope of big returns (speculation or gambling), which often goes along with magnifying the scale of one's financial returns (leverage). Financial markets grow and real economic activity prospers because derivatives make financial markets more efficient. This is a theme to which we return repeatedly throughout the book.

\section{Expanding Derivatives Markets}

Many factors have fueled the growth of derivatives markets. These include regulatory reforms, an increase in international commerce, population growth, political changes, the integration of the world's economy, and revolutionary strides in information technology (IT). The interrelated financial markets are now more susceptible to global shocks and financial crises. The financial world has become a mad, bad, and dangerous place-financially speaking! More pronounced business cycles, default by sovereign nations, high-risk leveraged bets by hedge funds, imprudent investment in complicated securities by unsophisticated investors, and fraudulent actions by rogue traders have the potential to shake financial markets to their core. Financial 
regulators exist to help prevent these catastrophes from happening. And if used properly, derivatives can also help to mitigate their effects on aggregate wealth.

To help achieve economic stability, the central bank of the US, the Federal Reserve System (often referred to as the Federal Reserve or simply the Fed), historically used monetary policy tools to keep interest rates stable. In 1979, the Fed also began targeting money supply growth. Despite this oversight, oil shocks and other supply-side disturbances created double-digit inflation rates in the 1970s and 1980s, which in turn led to double-digit US interest rates that wiggled more than ever before. These highly volatile interest rates created a need for securities to help corporations hedge this risk. Interest rate derivatives arose. The Chicago Board of Trade (CBOT; now part of the CME Group) developed the first interest rate derivative contract, the Ginnie Mae futures, in 1975 and the highly popular Treasury bond futures in 1977.

The foreign exchange market is one of the world's largest financial markets, where billions of dollars change hands daily. From the mid-1940s until the early 1970s, the world economy operated under the Bretton Woods system of fixed exchange rates-all the currencies were pegged to the US dollar, and the dollar was pegged to gold at $\$ 35$ per ounce. This stable monetary system worked well for decades. However, problems arose when gold prices soared. Countries converted their currencies into dollars and bought cheap gold from the US at the bargain price of $\$ 35$ per ounce, making huge profits. This was an arbitrage, a trade that makes riskless profits with no investment. Consequently, US gold reserves suffered a terrible decline. Because all currencies were tied to the dollar, the United States could not adjust the dollar's exchange rate to fix the problem. Instead, US president Richard Nixon abandoned the Bretton Woods system in 1971.

Currencies now float vis-à-vis one another in a so-called free market, although their values are frequently managed by central banks. Floating exchange rates are more volatile than fixed exchange rates, and to hedge this newly created currency risk, the huge foreign exchange derivatives market was created. In this regard, 1972 saw the opening of the International Monetary Market, a division of the Chicago Mercantile Exchange (CME or Merc; now part of the CME Group) to trade foreign currency futures. The world's first exchange-traded financial derivatives contract was born!

Given these regulatory changes and well-functioning interest rate and foreign currency derivatives markets, in the recent past, many economists believed that a new era of greater macroeconomic stability had dawned, dubbed the Great Moderation. During the two decades before the new millennium, fluctuations in the growth of real output and inflation had declined, stock market volatility was reduced, and business cycles were tamed.

However, the tide soon turned. In 2007-2009, many nations were mired in the Great Recession, with declining economic output and large unemployment. Stock market volatility, as measured by the widely followed VIX Index, shot up from 10 percent to an astonishing 89.53 percent in October 2008. ${ }^{1}$ Volatility had returned with a vengeance!

${ }^{1}$ See the Chicago Board Options Exchange's website, www.cboe.com/. 


\section{Two Economic Motives}

Regulatory changes have powerful impacts on markets. In fact, economics Nobel laureate Merton Miller argued in a 1986 article that regulations and taxes cause financial innovation. The reason is because derivative securities are often created to circumvent government regulations that prohibit otherwise lucrative transactions. And because most countries tax income from different sources (and uses) at different rates, financial innovations are often designed to save tax dollars as well. The desire to lower transactions costs also influences financial innovation. This perspective comes from another Nobel Prize-winning University of Chicago economist, Ronald Coase. Financial institutions often devise derivatives so that brokerage commissions, the difference between a securities dealer's buying and selling prices, are minimized (see Extension 1.1).

This leads us to an (almost) axiomatic truth that will guide us throughout the book: trading moves to those markets where transaction costs and regulatory constraints are minimized.

\subsection{Traded Derivative Securities}

A security, such as a stock or bond, gives its holder ownership rights over some assets and cash flows. It exists as a paper document or an electronic entry record and usually trades in an organized market. You may be familiar with bonds, which are debts of the issuer, and stocks, which give investors equity in the issuing company. Bonds and stocks require an initial investment. Most bonds pay back a promised amount (principal or par value) at maturity. Some bonds pay interest (coupons) on a regular basis, typically semiannually, while others are zero-coupon bonds that pay no interest but are sold at a discount from the principal. The investment in stock is never repaid. Stockholders usually get paid dividends on a quarterly basis as compensation for their stock ownership. Stock prices can increase and create capital gains for investors, and this profit is realized by selling the stock. Alternatively, stock prices can decrease and create capital losses.

Stocks and bonds are often used to create new classes of securities called derivatives, and that's where the variety comes in. As previously noted, a derivative security is a financial contract whose value is derived from one or more underlying assets or indexes - a stock, a bond, a commodity, a foreign currency, an index, an interest rate, or even another derivative security. Forwards, futures, and options are the basic types of derivatives. These are explained later in the book.

Some common terminology will help us understand the various derivative contracts traded:

1. Real assets include land, buildings, machines, and commodities, whereas financial assets include stocks, bonds, and currencies-both real and financial assets have tangible values.

2. Notional variables include interest rates, inflation rates, and security indexes, which exist as notions rather than as tangible assets. 


\section{EXTENSION 1.1: The Influence of Regulations, Taxes, and Transaction Costs on Financial Innovation}

In the old days, finance mainly consisted of legal issues, institutional description, and investment rules of thumb. This changed in the middle of the twentieth century, when financial economics sprang to life as an offshoot of economics. In a little over two decades, a new finance based on a rigorous analytics emerged. James Tobin and Harry Markowitz's portfolio theory (late 1940s and early 1950s); Franco Modigliani and Merton Miller's MEM propositions concerning the irrelevance of a firm's capital structure and dividend policy (late 1950s and early 1960s); William Sharpe, John Lintner, and Jan Mossin's capital asset pricing model (mid-1960s) and Fischer Black, Myron Scholes, and Robert Merton's option pricing model (early 1970s) established the basic theories. All these works have been celebrated with the Sveriges Riksbank (Bank of Sweden) Prize in Economic Sciences in Memory of Alfred Nobel, popularly known as the Nobel Prize in Economics. Other Nobel laureates, including Kenneth Arrow, Ronald Coase, Gerard Debreu, John Hicks, Paul Samuelson, and a well known economist, John Maynard Keynes, also contributed to finance. Two of these Nobel laureates' views concerned financial innovation.

\section{Miller's View: Regulations and Taxes Spur Financial Innovation}

What leads to revolutionary change in financial institutions and instruments? University of Chicago professor Merton Miller (1923-2000) argued that a major cause of financial innovation is regulations and taxes. Innovative financial securities are often created to avoid government regulations that prohibit otherwise lucrative transactions. And because most countries tax income from different sources (and uses) at different rates, derivative securities can be designed to save tax dollars.

Miller (1986) gives several examples:

- Regulation Q of the US placed a ceiling on the interest rate that commercial banks could pay on time deposits. Although this wasn't a problem during much of the postwar period, US interest rates rose above this ceiling during the late 1960s and early 1970s. When this occurred, US banks started losing customers. US banks realized, however, that Regulation $\mathrm{Q}$ did not apply to dollar-denominated time deposits in their overseas branches, and they soon began offering attractive rates via Eurodollar accounts. Interestingly, Regulation Q has long been repealed, but the Eurodollar market still continues to flourish.

- In the late 1960s, the US government imposed a 30 percent withholding tax on interest payments to bonds sold in the US to overseas investors. Consequently, for non-US citizens, the market for dollar-denominated bonds moved overseas to London and other money centers on the continent. This created the Eurobond market that still continues to grow today.

- The British government restricted dollar financing by British firms and sterling financing by non-British firms. Swaps, transactions in which counterparties exchange one form of cash flow for another, were developed to circumvent these restrictions.

- It was found in 1981 that US tax laws allowed a linear approximation for computing the implicit interest for long-term deep discount zero-coupon bonds. This inflated the present value of the interest deductions so much that a taxable corporation could actually profit by issuing a zero-coupon bond and giving it away! Not surprisingly, US corporations started issuing zero-coupon bonds in large numbers. This supply dwindled after the US Treasury fixed this blunder. 


\section{Coase's View: Transaction Costs are a Key Determinant of Economic Activity}

In 1937, Ronald Coase, a twenty-seven-year-old faculty member at the London School of Economics, published a simple but profound article titled "The Nature of the Firm." Coase argued that transactions incur costs, which come from "negotiations to be undertaken, contracts have to be drawn up, inspections have to be made, arrangements have to be made to settle disputes, and so on," and firms often appear when they can lower these transaction costs. With respect to financial markets, this logic implies that market participants often trade where they can achieve their objectives at minimum cost. Financial derivatives are often created so that these costs are minimized as well.

The lowering of transaction costs as an economic motivation was especially important during the 1990s and the new millennium. Changes in the economic and political landscape and the IT revolution have made it possible to significantly lower transaction costs, even eliminating age-old professions like brokers and dealers from many trading processes. For example, this motive was a major reason why traders migrated from Treasury securities to Eurodollar markets. Eurodollar markets, being free from Fed regulations and the peculiarities of the Treasury security auction cycle, have fewer market imperfections and lower liquidity costs.

Writing financial contracts on values or cash flows determined by future realizations of real asset prices, financial asset prices, or notional variables creates a derivative security. Early derivatives were created solely from financial and real assets. For example, in the 1960s, agricultural commodity-based futures were the most actively traded derivative contracts in the US. However, as the economy has evolved, notional variables and derivative securities based on these notional variables have also been created.

Notional variables are often introduced to help summarize the state of the economy. Just open the Wall Street Journal, and you will be amazed by the variety of indexes out there. You will find not only regular stock price indexes, such as the Dow-Jones and Standard and Poor's, but a whole range of other indexes, including those based on technology stocks, pharmaceuticals stocks, Mexican stocks, utility stocks, bonds, and interest rates. In addition, notional values are often useful for the creation of various derivatives. Perhaps the most famous example of this is a plain vanilla interest rate swap whose underlyings are floating and fixed interest rates.

\section{Diverse Views on Derivatives}

It is easy to speculate with derivatives: buy them, take huge one-sided bets, and laugh on the way to the bank or cry on the way to bankruptcy! Imprudent risk taking using derivatives is not uncommon, as illustrated by huge losses at many institutions, including Procter and Gamble $(\mathrm{P} \& \mathrm{G})$ and Barings Bank. People are uncomfortable with derivatives because they are complex instruments: difficult to understand, highly leveraged, and oftentimes not backed by sufficient collateral. High leverage means that small changes in the underlying security's price can cause large swings in the derivative's value. 
For these reasons, derivatives attract strong views from both sides of the aisle. The renowned investors Warren Buffett and Peter Lynch dislike derivatives. In his “Chairman's Letter" in Berkshire Hathaway's 2002 annual report, Buffett characterized derivatives as "time bombs, both for the parties that deal in them and the economic system." Lynch (1989) once stated that options and futures on stocks should be outlawed. These concerns were vindicated by the hundreds of billions of dollars of derivatives-related losses suffered by financial institutions during 2007 and 2008, which contributed to the severe economic downturn.

By contrast, former Fed chairman Alan Greenspan opined in a speech delivered before the Futures Industry Association in 1999 that derivatives "unbundle" risks by carefully measuring and allocating them "to those investors most able and willing to take it," a phenomenon that has contributed to a more efficient allocation of capital. And in Merton Miller on Derivatives, the Nobel laureate (Miller 1997, ix) assessed the impact of the "derivatives revolution" in glowing terms:

Contrary to the widely held perception, derivatives have made the world a safer place, not a more dangerous one. They have made it possible for firms and institutions to deal efficiently and cost effectively with risks and hazards that have plagued them for decades, if not for centuries. True, some firms and some financial institutions have managed to lose substantial sums on derivatives, but some firms and institutions will always find ways to lose money. Good judgment and good luck cannot be taken for granted.

Nobel laureate physicist David Gross provides a nice analogy for this disagreement. He views knowledge as expanding outward like a growing sphere and ignorance as the surface of that sphere. With respect to derivatives, we have accumulated significant knowledge over the past thirty years, but with respect to the causes of tsunami-like financial crises, there is still much for us to learn.

\section{Applications and Uses of Derivatives}

Derivatives trade in zero net supply markets, where each buyer has a matching seller. When hedging with a derivative, the other side of the transaction (counterparty) may be using it for speculative reasons. Hedging and speculation are often two sides of the same coin, and it is a zero-sum game because one trader's gain is the other's loss. Example 1.1 illustrates these concepts.

\section{EXAMPLE 1.1: Hedging and Speculation in a Derivative Transaction}

- April is the beginning of the corn-growing season, the commodity used in our example.

- Consider Mr. Short, a farmer in the midwestern United States. Short combines land, labor, seeds, fertilizers, and pesticides to produce cheap corn. He hopes to sell his corn harvest in September.

- Expertise in growing corn does not provide a crystal ball for forecasting September corn prices. If Short likes sleeping peacefully at night, he may decide to lock in the selling price for September corn when he plants it in April. 
To see how this is done, let's assume that everyone expects corn to be worth $\$ 10.00$ per bushel in September. Ms. Long, a trader and speculator, offers to buy Short's corn in September for $\$ 9.95$ per bushel, which is the forward price.

- To remove his risk, Short readily agrees to this forward price. Together they have created a forward contract - a promise to trade at a fixed forward price in the future. Although Short expects to lose 5 cents, he is happy to fix the selling price. The forward contract has removed output price uncertainty from his business. Short sees 5 cents as the insurance premium he pays for avoiding unfavorable future outcomes. Having hedged his corn selling price, Short can focus on what he knows best, which is growing corn.

- Ms. Long is also happy - not that she is wild about taking risks, but she is rational and willing to accept some unwanted risk, expecting to earn 5 cents as compensation for this activity. Later in the book, you will see how a speculator may manage her risk by entering into another transaction at a better price but on the other side of the market.

This simple example illustrates a key principle of historical importance-it was precisely to help farmers hedge grain prices that the first modern derivatives exchange, the CBOT, was established in 1848. Even the bitterest critics of derivatives have acknowledged this beneficial role.

Nowadays, the uses of derivatives are many. Consider the following possibilities:

- Hedging output price risk: A gold-mining company can fix the selling price of gold by selling gold futures.

- Hedging input cost: A sausage maker can hedge input prices by buying pork belly futures.

- Hedging currency risk: An American manufacturer buying machines from Germany for which the payment is due in three months can remove price risk from the dollar-euro exchange rates by buying a currency forward contract.

- Hedging interest rate risk: A pension fund manager who is worried that her bond portfolio will get clobbered by rising interest rates can use Eurodollar futures (or options on those futures) to protect her portfolio.

- Protecting a portfolio against a market meltdown: A money manager whose portfolio has reaped huge gains can protect these gains by buying put options.

- Avoiding market restrictions: A trader can avoid short selling restrictions that an exchange might impose by taking a sell position in the options or the futures market.

- Ruining oneself: A wretch can gamble away his inheritance with derivatives.

Before you finish this book, you will have a better understanding of the role derivatives play in each of these scenarios, except for the last one. The proclivity to gamble and lose arises from the depths of the human psyche, of which we have no special understanding. 


\section{A Quest for Better Models}

Great recognition for derivatives came in 1997, when Robert Merton and Myron Scholes won the Nobel Prize in Economics for developing the Black-ScholesMerton (BSM) model for option valuation. A co-originator of the model, Fischer Black, died earlier and missed receiving the prize, which is not given posthumously. This formula has become a staple of modern option pricing. Although extremely useful - options traders have it programmed into their computers-the BSM model makes a number of restrictive assumptions. These restrictive assumptions limit the application of the model to particular derivatives, those for which interest rate risk is not relevant (the BSM assumptions are discussed in later chapters).

Subsequent researchers have relaxed these restrictive assumptions and developed pricing models suitable for derivatives with interest rate risk. The standard model used on Wall Street for this application is the Heath-Jarrow-Morton (HJM) model. The HJM model can be used to price interest rate derivatives, long-lived financial contracts, and credit derivatives. Credit derivatives are among the newest class of derivatives to hit Wall Street. Started in the early 1990s, they now compose a huge market, and they are the subject of intense public debate following the 2007 credit crisis and their role in it.

Why develop and study better pricing models? Suppose you trade a variety of securities many times a day. If your models are better, you have an edge over your competitors in determining fair value. Over many transactions, when trading based on fair value - selling above fair value and buying below-your edge will pay off. Investment banking and Wall Street firms have no choice but to use the best models. It's just too important for their survival. Powerful models also help traders manage risk.

\subsection{Defining, Measuring, and Managing Risk}

Risk is an elusive concept and hard to define. In finance and business, risk can be defined and measured in many ways, none of them completely universal. Risk often depends on the user's perspective. We begin by looking at risk through a regulator's eyes. Next, we discuss risk from an individual's as well as an institutional trader's viewpoint. Finally, we discuss risk from a corporate management perspective.

\subsection{The Regulator's Classification of Risk}

In 1994, the international banking and securities regulators issued guidelines for supervising the booming derivatives market. The Basel Committee on Banking Supervision and the International Organization of Securities Commissions (IOSCO) recommended that for a stable world financial system, the national regulators had to 
ensure that banks and securities firms have adequate controls over the risks they incur when trading derivatives. ${ }^{2}$

The Basel Committee's Risk Management Guidelines for Derivatives (July 1994, 10-17) identified the following risks in connection with an institution's derivative activities. IOSCO's Technical Committee also issued a similar paper at the time: ${ }^{3}$

- Credit risk (including settlement risk) is the risk that a counterparty will fail to perform on an obligation.

- Market risk is the risk to an institution's financial condition resulting from adverse movements in the level or volatility of market prices. This is the same as price risk.

- Liquidity risk in derivative activities can be of two types: one related to specific products or markets and the other related to the general funding of the institution's derivative activities. The former is the risk that an institution may not be able to, or cannot easily, unwind or offset a particular position at or near the previous market price because of inadequate market depth or disruptions in the marketplace. Funding liquidity risk is the risk that the institution will be unable to meet its payment obligations on settlement dates or in the event of margin calls (which, we explain later, is equivalent to coming up with more security deposits).

- Operational risk (also known as operations risk) is the risk that deficiencies in information systems or internal controls will result in unexpected loss. This risk is associated with human error, system failures, and inadequate procedures and controls.

- Legal risk is the risk that contracts are not legally enforceable or documented correctly.

Managing market or price risk is the subject of this book. Initially, this topic attracted the sole attention of academics and practitioners alike. It still remains the most important risk for us to understand and to manage. The other risks only appear when normal market activity ceases. Credit risk evaluation is currently a subject of advanced research. As we explain later, exchange-traded derivatives markets are so designed that they are nearly free from credit risk. Liquidity risk is a persistent problem for traders who choose markets in which securities are not easily bought and sold. Chapter 3 discusses what makes markets illiquid. Operational risk is a reality with which one has to live. It is part of running a business, and appropriate management checks and balances reduce it. Legal risk isn't a problem for exchange-

\footnotetext{
${ }^{2}$ In 1974, the Group of Ten countries' central-bank governors established the Basel Committee on Banking Supervision. The Basel (or Basle) Committee formulates broad supervisory standards and recommends statements of best practice in the expectation that individual authorities will implement (see "History of the Basel Committee and Its Membership," www.bis.org/bcbs/history.htm). The International Organization of Securities Commissions, which originated as an inter-American regional association in 1974, was restructured as IOSCO in 1983. It has evolved into a truly international cooperative body of securities regulators (see www.iosco.org/about/about).

${ }^{3}$ For both reports, see www.bis.org/publ. These definitions are modified only slightly from those contained in the referenced report.
} 
traded contracts; however, it's a genuine problem in OTC markets. We leave this topic for the courts and law schools.

This jargon-laden Basel Committee report also cited the need for appropriate oversight of derivatives trading operations by boards of directors and senior management and the need for comprehensive internal control and audit procedures. It urged national regulators to ensure that firms and banks operate on a basis of prudent risk limits, sound measurement procedures and information systems, continuous risk monitoring, and frequent management reporting. The Basel Committee reports have been extremely influential in terms of their impact on derivatives regulation. We return to the issues again in the last chapter of the book, after mastering the basics of derivatives securities.

\subsection{Portfolio Risk Management}

Let us examine some issues in connection with portfolio risk management from the perspective of an individual or institutional trader. One of the first pearls of wisdom learned in finance is that to earn higher expected returns, one has to accept higher risks. This maxim applies to the risk of a portfolio, called portfolio risk.

This portfolio risk, when applied to a single security, can be broken into two parts: (1) nondiversifiable risk, which comes from market-wide sources, and (2) diversifiable risk, which is unique to the security and can be eliminated via diversification. Pioneering works by Markowitz (1952), Sharpe (1964), Lintner (1965), and Mossin (1966) gave us the capital asset pricing model-the alphas, the betas-ideas and concepts used by market professionals and finance academics.

Modern portfolio theory encourages investors to construct a portfolio in a topdown fashion. This involves three steps: (1) do an asset allocation, which means deciding how to spread your investment across broad asset classes such as cash, bonds, stocks, and derivatives; (2) do security selection, which means deciding which securities to hold within each asset class; and (3) periodically revisiting these issues, rebalancing and hedging the portfolio with derivatives as appropriate. Portfolio risk management is critical for investment companies such as hedge funds and mutual funds. These financial intermediaries receive money from the public, invest them in various financial securities, and pass on the gains and losses to investors after deducting expenses and fees.

\subsection{Corporate Financial Risk Management}

\section{Risks That Businesses Face}

To understand the risks that businesses face, let's take a look at a typical company's balance sheet, a vital accounting tool that gives a snapshot of its financial condition by summarizing its assets, liabilities, and ownership equity on a specific date. An asset provides economic benefits to the firm, whereas a liability is an obligation that requires payments at some future date. The difference between the two accrues 


\section{TABLE 1.1: Risks That a Business Faces}

\section{Assets}

Current assets

- Cash and cash equivalents (interest rate risk)

- Accounts receivable (interest rate risk, currency risk)

- Inventories (commodity price risk)

Long-term assets

- Financial assets (interest rate risk, market risk, currency risk)

- Property, plant, and equipment (interest rate risk, commodity price risk)

\section{Liabilities}

- Accounts payable (interest rate risk, currency risk)

- Financial liabilities (interest rate risk, currency risk)

- Pension fund obligations (interest rate risk, market risk)

\section{Equity}

- Ownership shares

to the owners of the company as shareholder's equity (hence the identity assets equals liabilities plus shareholder's equity). Depending on whether they are for the short term (one year or less) or for the long haul, assets and liabilities are further classified as current or noncurrent, respectively. Table 1.1 illustrates some risks that affect different parts of a firm's balance sheet.

We see that a typical company faces three kinds of risks: currency risk, interest rate risk, and commodity price risk. These are the three components of market risk:

1. If a big chunk of your business involves imports and exports or if you have overseas operations that send back profits, then exchange rate risk can help or hurt. This is a risk that you must understand and decide whether to hedge using currency derivatives.

2. No less important is interest rate risk. It is hard to find companies like Microsoft, with tens of billions of dollars in cash holdings that can be quickly deployed for value-enhancing investments. Most companies are cash strapped. Interest rate fluctuations therefore affect their cost of funds and influence their investment activities. Interest rate derivatives offer many choices for managing this risk.

3. Unless a financial company, most businesses are exposed to fluctuations in commodity prices. A rise in commodity prices raises the cost of buying inputs that may not always be passed on to customers. For example, if crude oil prices go up, so does the price of jet fuel and an airline's fuel costs. Sometimes airlines levy a fuel surcharge, but it is unpopular and often rolled back. Another option is to hedge such risks by using oil-price derivatives. 


\section{Nonhedged Risks}

Despite the development of many sophisticated derivatives useful for hedging (and speculation), some risks are difficult, if not impossible, to hedge. For example, it is very hard to hedge operational risk. Recall that operational risk is the risk of a loss owing to events such as human error, fraud, or faulty management. Although a bank can buy insurance to protect itself from losses due to fire, no insurance company will insure a bank against the risk that a trader presses the wrong computer button and enters the wrong bond trade. For examples of such operational risk losses, see Chapter 26. Other difficult or impossible to hedge risks include losses because of changes in commodity prices for which there is no futures contract trading.

We will now take a bird's-eye view of how a blue chip company uses derivatives for risk management.

\section{Risk Management in a Blue Chip Company}

The SFAS (Statement of Financial Accounting Standards) No. 133, "Accounting for Derivative Instruments and Hedging Activities," as amended, requires US companies to report all derivative instruments on the balance sheet at fair value and establishes criteria for designation and effectiveness of hedging relationships. Let's take a look at Form 10-K (annual report) filed with the US Securities and Exchange Commission by Procter \& Gamble (P\&G), a giant company that owns some of the world's best-known consumer product brands. ${ }^{4}$

$P \& G$ heavily uses derivatives for risk management. A careful reading of this annual report reveals several interesting characteristics of $P \& G$ 's risk management activity:

- $P \& G$ is exposed to the three categories of risk that we just mentioned.

- P\&G consolidates these risks and tries to offset them naturally, which means some risks cancel each other. It then tries to hedge the rest with derivatives.

- $\mathrm{P} \& \mathrm{G}$ does not hold derivatives for trading purposes.

- P\&G monitors derivatives positions using techniques such as market value, sensitivity analysis, and value at risk. When data are unavailable, $P \& G$ uses reasonable proxies for estimating volatility and correlations of market factors.

- P\&G uses interest rate swaps to hedge its underlying debt obligations and enters into certain currency interest rate swaps to hedge the company's foreign net investments.

- P\&G manufactures and sells its products in many countries. It mainly uses forwards and options to reduce the risk that the company's financial position will be adversely affected by short-term changes in exchange rates (corporate policy limits how much it can hedge).

- P\&G sometimes uses futures, options, and swaps to manage the price volatility of raw materials. 
- P\&G designates a security as a hedge of a specific underlying exposure and monitors its effectiveness in an ongoing manner.

- P\&G's overall currency and interest rate exposures are such that the company is 95 percent confident that fluctuations in these variables (provided they don't deviate from their historical behavior) would not materially affect its financial statements. $P \& G$ expects significant risk neither from commodity hedging activity nor from credit risk exposure.

- P\&G grants stock options and restricted stock awards to key managers and directors (employee stock options are valued by using a binomial model that you will learn to implement in Part III of this book).

How does one understand, formulate, and implement hedging and risk management strategies like the ones adopted by $\mathrm{P} \& \mathrm{G}$ ? Read on, for that is a major purpose of this book.

\subsection{Risk Management Perspectives in This Book}

The Basel Committee's risk nomenclature has become the standard way that market participants see, classify, and understand different types of risks in derivatives markets. In this book, we restrict our focus mainly to market or price risk. For this we usually wear four separate hats and look at risk management from the perspectives of an individual trader, a financial institution, a nonfinancial corporation, and a dealer.

In early chapters, we start by examining financial securities and their markets from an individual trader's standpoint. This simple and intuitive approach makes it easier to understand the material. It's also historically correct because many markets, including those for stocks, futures, and options, were started by individual traders.

But today's derivatives markets have become playing fields for financial institutions. This is no surprise because as an economy develops, a greater share of its gross domestic product comes from services, of which financial institutions are a major constituent. These institutions generally engage in sophisticated ways of investing. We discuss derivatives and risk management from a financial institution's viewpoint because you may eventually be working for one, or at the very least, you are likely to have financial dealings with such institutions on a regular basis. The term institution is a catchall phrase that includes commercial and investment banks, insurance companies, pension funds, foundations, and finance companies such as mutual funds and hedge funds. In later chapters, we study swaps and interest rate derivatives, whose markets are the near-exclusive domain of financial (and nonfinancial) institutions.

Nonfinancial companies engage in more real activity than financial companies. Nonfinancials give us food, develop medicines, build homes, manufactures cars, refine crude oil to create gasoline, generate electricity, provide air travel, create household chemicals, and make computers to save and express our ideas. They buy one or more inputs to produce one or more outputs, and different kinds of risk (including exchange rate risk, interest rate risk, and commodity price risk) can 
seriously affect their businesses. This takes us to financial engineering, which applies engineering tools to develop financial contracts to meet the needs of an enterprise. This is our third hat: looking at derivatives from a nonfinancial company's risk management perspective.

Sometimes, we take a dealer's perspective. A dealer is a financial intermediary who posts prices at which she can buy (wholesale or bid price) or sell (retail or ask price) securities to her customers. Trying to make a living from the spread, or the difference between these two prices, the dealer focuses on managing books, which means carefully controlling her inventory of securities to minimize risk. Both an individual trader and a financial institution can play a dealer's role in financial markets.

These four perspectives aren't ironclad, and we flit from one to another as the discussion demands. In the final analysis, this shifting from one category to another isn't bad for the aspiring derivatives expert. In the words of the immortal bard William Shakespeare, from Hamlet (if we take the liberty of forgetting about spirits and instead apply this to the mundane), "there are more things in heaven and earth, Horatio, than are dreamt of in your philosophy." So stay awake and study derivatives, develop a sense for risky situations, understand the markets, learn pricing models, and know their limitations.

\subsection{Summary}

1. Derivatives are financial securities that derive their value from some underlying asset price or index. Derivatives are often introduced to hedge risks caused by increasingly volatile asset prices. For example, during the last three decades of the twentieth century, we have moved away from a regime of fixed exchange rates to a world of floating exchange rates. The market-determined foreign exchange rates increased their volatility, creating the need for foreign currency derivatives.

2. In today's interconnected global economy, risks coming from many different sources can make or break businesses. Derivatives can both magnify risk (leverage and gambling) or reduce risk (hedging). Although gambling with derivatives remains popular in some circles, and derivatives mishaps grab newspaper headlines, most traders prudently use derivatives to remove unwanted risks affecting their businesses.

3. There are many types of risk. Besides market risk, the regulators are concerned about credit risk, liquidity risk, operational risk, and legal risk. Though unglamorous, these risks can eat away profits and jolt the running of smooth-functioning derivatives markets.

4. Derivatives are very useful for managing the risk of a portfolio, which is a collection of securities. Portfolio risk management is important for both individual investors and financial companies such as hedge funds and mutual funds. Many businesses are exposed to exchange rate risk, interest rate risk, and commodity price risk and use derivatives to hedge them. US companies report derivatives usage and exposure on Form 10-K filed annually with the Securities and Exchange Commission. For example, $\mathrm{P} \& \mathrm{G}$ reports that it is exposed to exchange rate risk, 
interest rate risk, commodity price risk, and credit risk. P\&G consolidates risks and attempts to offset them naturally and tries to hedge the remaining risk with derivatives.

5. We look at risk management from several different perspectives: that of an individual trader, a financial institution, a nonfinancial corporation, and a dealer. These perspectives aren't ironclad, and we flit from one to another as the discussion demands.

\subsection{Cases}

Hamilton Financial Investments: A Franchise Built on Trust (Harvard Business School Case 198089-PDF-ENG). The case discusses various risks faced by a finance company that manages mutual funds and provides discount brokerage services.

Grosvenor Group Ltd. (Harvard Business School Case 207064-PDF-ENG). The case considers whether a global real estate investment firm should enter into a property derivative transaction to alter its asset allocation and manage its business.

Societe Generally (A and B): The Jerome Kerviel Affair (Harvard Business School Cases 110029 and 110030-PDF-ENG). The case illustrates the importance of internal control systems in a business environment that involves a high degree of risk and complexity in the context of a derivatives trader indulging in massive directional trades that went undetected for over a year.

\subsection{Questions and Problems}

1.1. What is a derivative security? Give an example of a derivative and explain why it is a derivative.

1.2. List some major applications of derivatives.

1.3. Evaluate the following statement: "Hedging and speculation go hand in hand in the derivatives market."

1.4. What risks does a business face?

1.5. Explain why financial futures have replaced agricultural futures as the most actively traded contracts.

1.6. Explain why derivatives are zero-sum games.

1.7. Explain why all risks cannot be hedged. Give an example of a risk that cannot be hedged.

1.8. What is a notional variable, and how does it differ from an asset's price?

1.9. Explain how derivatives give traders high leverage.

1.10. Explain the essence of Merton Miller's argument explaining what spurs financial innovation. 
1.11. Explain the essence of Ronald Coase's argument explaining what spurs financial innovation.

1.12. Does more volatility in a market lead to more use of financial derivatives? Explain your answer.

1.13. When the international banking regulators defined risk in their 1994 report, what definition of risk did they have in mind? How does this compare with the definition of risk from modern portfolio theory?

1.14. What's the difference between real and financial assets?

1.15. Explain the differences between market risk, credit risk, liquidity risk, and operational risk.

1.16. Briefly present Warren Buffett's and Alan Greenspan's views on derivatives.

1.17. Consider the situation in sunny Southern California in 2005, where house prices have skyrocketed over the last few years and are at an all-time high. Nathan, a software engineer, buys a second home for $\$ 1.5$ million. Five years back, he bought his first home in the same region for $\$ 350,000$ and financed it with a thirty-year mortgage. He has paid off $\$ 150,000$ of the first loan. His first home is currently worth $\$ 900,000$. Nathan plans to rent out his first home and move into the second. Is Nathan speculating or hedging?

1.18. During the early years of the new millennium, many economists described the past few decades as the period of the Great Moderation. For example,

- an empirical study by economists Olivier Blanchard and John Simon found that "the variability of quarterly growth in real output (as measured by its standard deviation) had declined by half since the mid-1980s, while the variability of quarterly inflation had declined by about two thirds."

- an article titled "Upheavals Show End of Volatility Is Just a Myth" in the Wall Street Journal, dated March 19, 2008, observed that an important measure of stock market volatility, "the Chicago Board Options Exchange's volatility index, had plunged about 75\% since October 2002, the end of the latest bear market, through early 2007"; the article also noted that "in the past 25 years, the economy has spent only 16 months in recession, compared with more than 60 months for the previous quarter century."

a. What were the explanations given for the Great Moderation?

b. Does the experience of the US economy during January 2007 to December 2010 still justify characterizing this as a period of Great Moderation? Report (1) quarterly values for changes in the gross domestic product, (2) quarterly values for changes in the inflation rate, and (3) the volatility VIX Index value during this period to support your answer.

1.19. Drawing on your experience, give examples of two risks that one can easily hedge and two risks that one cannot hedge. 
1.20. Download Form 10-K filed by $\mathrm{P} \& \mathrm{G}$ from the company's website or the US Securities and Exchange Commission's website. Answer the following questions based on a study of this report:

a. What are the different kinds of risks to which $P \& G$ is exposed?

b. How does $P \& G$ manage its risks? Identify and state the use of some derivatives in this regard.

c. Name some techniques that $P \& G$ employs for risk management.

d. Does P\&G grant employee stock options? If so, briefly discuss this program. What valuation model does the company use for valuing employee stock options? 